\title{
Genetic Basis of Primary Angle Closure Glaucoma: The Role of Collagens and Extracellular Matrix
}

\author{
Elahe Elahi, PhD \\ Department of Biotechnology, College of Science, University of Tehran, Tehran, Iran \\ ORCID: \\ Elahe Elahi: https://orcid.org/0000-0002-6897-2223
}

J Ophthalmic Vis Res 2020; 15 (1): 1-3

Glaucoma is a heterogeneous group of optic neuropathies characterized by a specific pattern of optic nerve degeneration and visual field loss that is usually accompanied by increased intraocular pressure (IOP).$^{[1]}$ It is a major cause of irreversible blindness worldwide. ${ }^{[2]}$ Primary glaucoma is classified into three major forms based on the anatomy of the anterior chamber drainage angle of the eye and the age of onset: primary congenital glaucoma (PCG), primary open angle glaucoma (POAG), and primary angle closure glaucoma (PACG) ${ }^{[1]}$ In glaucoma patients with increased IOP, the increase is thought to be mainly due to impaired drainage of aqueous humor from the anterior chamber. ${ }^{[3]}$

The etiology of all forms of glaucoma includes a genetic component as evidenced by variable prevalence in different ethnic groups, observations on familial clustering, and results of pedigree and sib-pair studies. For PCG, which is usually a monogenetic Mendelian disease, three causative genes have been identified. ${ }^{[4-7]}$ POAG and PACG are generally considered complex multifactorial disorders. ${ }^{[8]}$ Several POAG-causing genes have been identified, but mutations in these account for disease in less than $10 \%$ of patients. ${ }^{[9-13]}$

Compared to the other forms of glaucoma, there is much less definitive genetic data pertaining to PACG. This likely reflects the contribution of multiple genetic and perhaps environmental factors that affect various anatomical and functional features associated with PACG. PACG is an important public health entity. It is estimated that 15.7 million individuals in the world are affected with PACG. It is projected that 21 million will be affected by 2020 , and that PACG by that time will cause bilateral blindness in 5.3 million people. ${ }^{[14-16]}$ Most PACG patients are from Asia, particularly China, Mongolia, Singapore, and India.
Ultimately, the defining feature of PACG in individuals with glaucomatous optic nerve damage is iridocorneal angle closure. Recently, COL18A1 which encodes collagen type XVIII was identified as a gene that affects angle closure in patients of three unrelated families. ${ }^{[17]}$ The inheritance pattern of angle closure causing mutations in COL18A1 was autosomal dominant. It appears that mutations in this gene may cause angle closure in the fourth decade of life or later. Furthermore, COL18A1 mutations are not expected to be a common cause of angle closure-related phenotypes. The significance of having identified COL18A1 as a potential PACG-causing gene lies in emphasis on the importance of collagens and the extracellular matrix in glaucoma pathology.

In pursuit of identifying genes that contribute to PACG disease, association studies and candidate gene studies have been performed and the results of these have implicated possible roles for several genes. ${ }^{[18-25]}$ However, these findings are not generally considered definitive, and putative roles of genes suggested by some studies were not confirmed in independent studies. Factors known to be associated with PACG include hyperoptic refractive error, shallow anterior chamber, thick crystalline lens, short axial length, small corneal diameter, and narrow iridocorneal angle. ${ }^{[26-28]}$ Clearly, some of these also associate with each other. In an article published in this issue of the Journal of Ophthalmic and Vision Research, the authors relied on transcriptome data pertaining to eye anterior segment tissues to select five single nucleotide polymorphisms (SNPs) whose genotypes may be associated with PACG among patients of Northeast Iran. ${ }^{[29-31]}$ Interestingly, one of the SNPs for which an association with PACG was reported is positioned in a gene (FERMT2) that 
encodes a component of the ECM. Results of an association study that included tens of thousands of patients and controls had also implicated the same gene with respect to PACG. ${ }^{[20]}$

There exists accumulating evidence that implicates various collagens specifically and the extracellular matrix more generally in the pathogenesis of glaucoma. ${ }^{[7,32-36]}$ Eight loci were identified in one or both of two recent large genome-wide association (GWA) studies on PACG patients, and COL11A1 that encodes one of the alpha chains of type $\mathrm{XI}$ collagen was one of the genes identified in both of the studies. ${ }^{[18,20]}$ An SNP in COL1A1 was associated with increased risk of myopia in Japanese and Chinese individuals. ${ }^{[37,38]}$ A GWA study of PACG in a dog breed identified COL1A2 as a susceptibility locus. ${ }^{[39]}$ And of course, COL18A1 was identified as a gene that affects iridocorneal angle closure in humans. ${ }^{[17]}$ In addition to collagens, genes with roles in the extracellular matrix and also associated with glaucoma include MMP-9, MTHFR, $\angle T B P 2, C Y P 1 B 1$, and SPARC. It has been suggested that inter-individual differences in tolerance to IOP as reflected in glaucoma diagnosis with normal tension in some and ocular hypertension without glaucoma in others reflect variations in biomechanical properties of the extracellular matrix of relevant

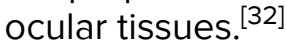

\section{REFERENCES}

1. Ray K, Mukhopadhyay A, Acharya M. Recent advances in molecular genetics of glaucoma. Mol Cell Biochem 2003;253:223-231.

2. Thylefors $B$, Negrel AD, Pararajasegaram R, Dadzie KY. Global data on blindness. B World Health Organ 1995;73:115-121.

3. Tamm ER, Braunger BM, Fuchshofer R. Intraocular pressure and the mechanisms involved in resistance of the aqueous humor flow in the trabecular meshwork outflow pathways. Prog Mol Biol Trans/ 2015;134:301-314.

4. Souma T, Tompson SW, Thomson BR, Siggs OM, Kizhatil $\mathrm{K}$, Yamaguchi S, et al. Angiopoietin receptor TEK mutations underlie primary congenital glaucoma with variable expressivity. J Clin Invest 2016;126:2575-2587.

5. Stoilov I, Akarsu AN, Sarfarazi M. Identification of three different truncating mutations in cytochrome P4501B1 (CYP1B1) as the principal cause of primary congenital glaucoma (Buphthalmos) in families linked to the GLC3A locus on chromosome 2p21. Hum Mol Genet 1997;6:641647.

6. Ali M, McKibbin M, Booth A, Parry DA, Jain P, Riazuddin $\mathrm{SA}$, et al. Null mutations in LTBP2 cause primary congenital glaucoma. Am J Hum Genet 2009;84:664-671.

7. Narooie-Nejad M, Paylakhi SH, Shojaee S, Fazlali Z, Rezaei Kanavi M, Nilforushan N, et al. Loss of function mutations in the gene encoding latent transforming growth factor beta binding protein 2, LTBP2, cause primary congenital glaucoma. Hum Mol Genet 2009;18:3969-3977.

8. Sakurada Y, Mabuchi F. Advances in glaucoma genetics. Prog Brain Res 2015;220:107-126.

9. Stone EM, Fingert JH, Alward WL, Nguyen TD, Polansky JR, Sunden SL, et al. Identification of a gene that causes primary open angle glaucoma. Science 1997;275:668670.

10. Monemi S, Spaeth G, DaSilva A, Popinchalk S, Ilitchev $\mathrm{E}$, Liebmann J, et al. Identification of a novel adult-onset primary open-angle glaucoma (POAG) gene on 5q22.1. Hum Mol Genet 2005;14:725-733.

11. Rezaie T, Child A, Hitchings R, Brice G, Miller L, Coca-Prados $\mathrm{M}$, et al. Adult-onset primary open-angle glaucoma caused by mutations in optineurin. Science 2002;295:1077-1079.

12. Pasutto F, Matsumoto T, Mardin CY, Sticht H, Brandstatter $\mathrm{JH}$, Michels-Rautenstrauss $\mathrm{K}$, et al. Heterozygous NTF4 mutations impairing neurotrophin-4 signaling in patients with primary open-angle glaucoma. Am J Hum Genet 2009;85:447-456.

13. Fingert JH, Robin AL, Stone JL, Roos BR, Davis LK, Scheetz TE, et al. Copy number variations on chromosome 12q14 in patients with normal tension glaucoma. Hum Mol Genet 2011;20:2482-2494.

14. Bonomi L. Epidemiology of angle-closure glaucoma. Acta Ophthalmol Scand 2002;236:11-13.

15. Quigley HA, Broman AT. The number of people with glaucoma worldwide in 2010 and 2020. Brit J Ophthalmol 2006;90:262-267.

16. Cedrone C, Mancino R, Cerulli A, Cesareo M, Nucci C. Epidemiology of primary glaucoma: prevalence, incidence, and blinding effects. Prog Brain Res 2008;173:3-14.

17. Suri F, Yazdani S, Chapi M, Safari I, Rasooli P, Daftarian $\mathrm{N}$, et. al. COL18A1 is a candidate eye iridocorneal angleclosure gene in humans. Hum Mol Genet 2018;27:37723786.

18. Vithana EN, Khor CC, Qiao C, Nongpiur ME, George R, Chen LJ, et al. Genome-wide association analyses identify three new susceptibility loci for primary angle closure glaucoma. Nat Genet 2012;44:1142-1146.

19. Nongpiur ME, Khor CC, Jia H, Cornes BK, Chen LJ, Qiao C, et al. ABCC5, a gene that influences the anterior chamber depth, is associated with primary angle closure glaucoma. PLOS Genet 2014;10:e1004089.

20. Khor CC, Do T, Jia H, Nakano M, George R, Abu-Amero K, et al. Genome-wide association study identifies five new susceptibility loci for primary angle closure glaucoma. Nat Genet 2016;48:556-562.

21. Wang IJ, Chiang TH, Shih YF, Lu SC, Lin LL, Shieh JW, et al. The association of single nucleotide polymorphisms in the MMP-9 genes with susceptibility to acute primary angle closure glaucoma in Taiwanese patients. Mol Vis 2006;12:1223-1232.

22. Awadalla MS, Thapa SS, Burdon KP, Hewitt AW, Craig JE. The association of hepatocyte growth factor (HGF) gene with primary angle closure glaucoma in the Nepalese population. Mol Vis 2011;17:2248-2254.

23. Awadalla MS, Thapa SS, Hewitt AW, Craig JE, Burdon KP. Association of eNOS polymorphisms with primary angle-closure glaucoma. Invest Ophthalmol Vis Sci 2013;54:2108-2114. 
24. Ayub H, Khan MI, Micheal S, Akhtar F, Ajmal M, Shafique $\mathrm{S}$, et al. Association of eNOS and HSP7O gene polymorphisms with glaucoma in Pakistani cohorts. Mol Vis 2010;16:18-25.

25. Shi H, Zhang J, Zhu R, Hu N, Lu H, Yang M, et al. Primary angle closure and sequence variants within MicroRNA binding sites of genes involved in eye development. PLOS ONE 2016;11:e0166055.

26. Congdon NG, Youlin Q, Quigley H, Hung PT, Wang $\mathrm{TH}, \mathrm{Ho} \mathrm{TC}$, et al. Biometry and primary angle-closure glaucoma among Chinese, white, and black populations. Ophthalmology 1997;104:1489-1495.

27. Foster PJ, Alsbirk PH, Baasanhu J, Munkhbayar D, Uranchimeg D, Johnson GJ. Anterior chamber depth in Mongolians: variation with age, sex, and method of measurement. Am J Ophthalmol 1997;124:53-60.

28. Salmon JF. Predisposing factors for chronic angle-closure glaucoma. Prog Retin Eye Res 1999;18:121-132.

29. Yousefian A, Shokoohi-Rad S, Abbaszadegan MR, Morshedi Rad D, Zargari S, Milanzadeh S, et al. Primary Angle Closure Glaucoma-associated Genetic Polymorphisms in Northeast Iran. J Ophthalmic Vis Res 2019;15:45-52.

30. Westra HJ, Peters MJ, Esko T, Yaghootkar H, Schurmann $C$, Kettunen J, et al. Systematic identification of trans eQTLs as putative drivers of known disease associations. Nat Genet 2013;45:1238-1243.

31. Consortium G. The genotype-tissue expression (GTEx) pilot analysis: multitissue gene regulation in humans. Science 2015;348:648-660.

This is an open access journal, and articles are distributed under the terms of the Creative Commons Attribution-NonCommercial-ShareAlike 4.0 License, which allows others to remix, tweak, and build upon the work non-commercially, as long as appropriate credit is given and the new creations are licensed under the identical terms.
32. Huang W, Fan Q, Wang W, Zhou M, Laties AM, Zhang X. Collagen: a potential factor involved in the pathogenesis of glaucoma. Med Sci Monitor Basic Res 2013;19:237-240.

33. Vithana EN, Aung T, Khor CC, Cornes BK, Tay WT, Sim $X$, et al. Collagen-related genes influence the glaucoma risk factor, central corneal thickness. Hum Mol Genet 2011;20:649-658.

34. Aihara M, Lindsey JD, Weinreb RN. Ocular hypertension in mice with a targeted type I collagen mutation. Invest Ophthalmol Vis Sci 2003;44:1581-1585.

35. Sawaguchi S, Yue BY, Fukuchi T, Abe H, Suda K, Kaiya T, et al. Collagen fibrillar network in the optic nerve head of normal monkey eyes and monkey eyes with laser-induced glaucoma-a scanning electron microscopic study. Curr Eye Res 1999;18:143-149.

36. Suri F, Yazdani S, Elahi E. Glaucoma in Iran and contributions of studies in Iran to the understanding of the etiology of glaucoma. J Ophthal Vis Res 2015;10:68-76.

37. Inamori $\mathrm{Y}$, Ota M, Inoko H, Okada E, Nishizaki R, Shiota T, et al. The COL1A1 gene and high myopia susceptibility in Japanese. Hum Genet 2007;122:151-157.

38. Zhang D, Shi Y, Gong B, He F, Lu F, Lin H, et al. An association study of the COL1A1 gene and high myopia in a Han Chinese population. Mol Vis 2011;17:3379-3383.

39. Ahram DF, Cook AC, Kecova H, Grozdanic SD, Kuehn $\mathrm{MH}$. Identification of genetic loci associated with primary angle-closure glaucoma in the basset hound. Mol Vis 2014;20:497-510.

\begin{tabular}{|l|}
\hline \multicolumn{1}{|c|}{ Access this article online } \\
\hline Website: \\
https://knepublishing.com/index.php/JOVR \\
\hline DOI: \\
10.18502/jovr.v15i1.5930 \\
\hline
\end{tabular}

How to cite this article: Elahi E. Genetic Basis of Primary Angle Closure Glaucoma: The Role of Collagens and Extracellular Matrix. J Ophthalmic Vis Res 2020;15:1-3. 